\title{
CREATIVE ECONOMY: HOW THE INTERFACE OF UBER EATS AND IFOOD COULD CHANGE YOUR MENU
}

Renata Cristina da Silva Monty

renata.monty@gmail.com

Rio de Janeiro State University - UERJ, Rio de Janeiro, Rio de Janeiro, Brazil.

\begin{abstract}
The objective of this paper is to analyze the impact of Creative Economy to customers of food apps in Brazil. In the first part, it is described how cultural products regarding food and cooking in Brazil work. In the second part, a descriptive analysis of the apps iFood and UberEats is proposed in order to understand how the materiality of these products, as an interface, could influence the choice of the menu. For this, food is regarded as a cultural good. The concept immortalized by Marshall McLuhan "the medium is the message" assists us in the descriptive exercise of verifying how information and communication technologies (TICS) affect the experience of eating in the contemporary world. From this point of view, a comparative exercise regarding the materiality of the applications is proposed.
\end{abstract}

Keywords: Creative Economy; Materialities; Sensorialities; Digital Media; Gastronomy. 
Brazilian Journal of Operations \& Production Management

Volume 15, Número 3, 2018, pp. 413-419

DOI: 10.14488/BJOPM.2018.v15.n3.a8

\section{INTRODUCTION}

A member of the punk movement in the 1970's, Alex Atala is one of the most acclaimed Brazilian chefs. A controversial figure, Atala has already caused amazement at serving Amazonian ants with gold leaves in his exquisite D.O.M. restaurant in São Paulo. At the same time, D.O.M. appears on the list of the top 50 restaurants in the world by the British magazine "The Restaurant". Popular on social networks", the chef has raised questions by stating that "the largest social network in the world is not Facebook, but food, as it connects millions of people"2. Perhaps this maxim of the cook can provide clues to the avalanche of digital cultural products related to gastronomy that have emerged in recent years in Brazil and in the world. The act of eating is universal, going through material and symbolic aspects, and the experience surrounding food has been explored in different ways with the advent of communication and information technologies (TICS), in the context of web 2.0, characterized by the collaboration of users themselves in the production of content, through mobile applications, television programs, websites, blogs, web pages and social networking profiles.

As researchers of Social Communication, our interest surrounds cooking as a cultural good and how its consumption has been transformed through the use of new technologies, especially by delivery applications and online reviews. In the article "Culinary as intangible cultural heritage ( $A$ culinária como patrimônio cultural immaterial, in Portuguese)", Giustina (2009) approaches food from the standpoint of everyday eating habits, which are part of the habits of nutrition and traditions of certain peoples:

Identity, taste and know-how qualify cuisine as an intangible heritage of a culture. It is the manifestation of memory and history in an activity that is considered mundane, but which is easily perceived and understood as part of the past (Giustina, 2009, p. 1).

In this context, food is not our only object of investigation, nor is the techniques of preparation, but the media contents and their interactions with the gastronomic culture. The concept immortalized by Marshall McLuhan "the medium is the message" (2005) assists us in the exercise of verifying how communication technologies affect the experience of eating in the contemporary world. From this point of view, it is believed that the theories of materialities, in which "the idea that the whole expression of a sense - the

1 On Instagram Alex Atala has about 584 thousand followers; on Twitter, he has 36 thousand; and on Facebook he has 381 thousand followers. The account was held on July 12, 2017.

2 In order to read the interview, access: goo.gl/g22ghD. Accessed on 14.07.2017. thought of an author, for example - is deeply determined by the material and the historical circumstances of his everyday reality, by the materialities that constitute their cultural world" (Felinto et Andrade, 2005), could help us compare Uber Eats and iFood.

For contextualization purposes, it is worth highlighting the innumerable digital contents on gastronomy produced in recent years in Brazil. On television alone, there are more than 30 programs, such as the success Masterchef. A hybrid of talent show and reality show (Marquioni et Andacht, 2016, p. 1) aired on Band TV; it transforms an everyday activity, the act of cooking, into a performance game whose challenge is to produce a specific dish with presentation and flavor, in a predetermined period of time. The language of the program brings some suspense and tension in relation to the preparation of food, leaving the viewer stuck to the attraction. In the end, each dish is rated by three seasoned chefs. In May 2017, the reality show reached a record audience on Brazilian open TV3.

Faced with this success, the repercussion of candidate performances and eliminations are commented on Twitter and Facebook with the use of hashtags, resulting in a simultaneous practice of watching TV and participating online. The boundaries of television are broken in the so-called "second screen", through the use of tablets and smartphones (Almeida, 2015), resulting in hybrids called "TV Transmedia" (Fechine et al, 2013) or "hyper television" (Scolari, 2008). The success of "Masterchef" certainly contributed to the increase of interest in the subject, stimulating other attractions for Brazilian TV4.

However, not only television programs gained visibility among the public. It could be said that Grandma's recipe book became much more visual. On social networks, videos

3 The episode "MasterChef" of May 30, 2017 recorded the highest audience of the season and came to surpass the program of Pedro Bial on TV Globo, one of the most popular broadcasters in the country. Available at: http://bit.ly/2u9z9GC

4 On broadcast TV, there are many entertainment products such as: "Chefs sob pressão", "Bake off Brasil" and "Hell's Kitchen", on SBT TV, "Melhor para você", on Rede TV, "Mais Você", on Globo TV, and "Batalha dos cozinheiros", on Record TV. On Netflix, there are shows such as "Chef's Table", "Jiro - Dream's of Sushi", "Somm: dentro da garrafa". The cable TV channel GNT brings together the largest number of Brazilian programs, such as "Cozinha Prática com Rita Lobo", "Um Brinde ao Vinho", "Tempero de família", "Vida mais Bela", "Que seja doce", "Cozinha colorida da Capim", "Cozinheiros em ação", "Diário de uma vegana", "Diário do Olivier", "Papinhas e Comidinhas", "Que marravilha!", "Rainha da cocada", "Receitas da Carolina", besides "Jamie Oliver" and "The Taste Brasil". Sony features "Top Chef". Fox Life presents the shows "Programa da Palmirinha" and "Homens Gourmet". 
of fast recipes are common, as is the case of the web pages Tasty Demais and Tastemade, on Facebook, with about 16 million followers. According to Tastemade, his videos total more than $\mathbf{3 0 0}$ million views a month, while Tasty Demais claims to have 500 million views a month. The latter appeared as a brand in American BuzzFeed and, in 2016, created its Brazilian version, due to the considerable number of hits in the country, according to video producer Gaspar José, in an interview with Galileu Magazine ${ }^{5}$. The aesthetics of the videos deserve to be mentioned because, in addition to the easy preparation mode, the takes are from a superior camera that focuses only on the utensils, ingredients and hands of the cook. In general, they last about 15 seconds, using the technique of time lapse (which accelerates the actions), differentiating it from the products for TV, which have a slower narrative. The success of these videos is such that an El País ${ }^{6}$ story compares views of Justin Bieber's new music video with Tasty's recipe for mini-cheesecake wafers. The report reads: "Sweet beats the album by 38 million views."

On Instagram, it is common to see photos and videos of food, as well as reports of gastronomic experiences of customers in bars, restaurants, food trucks and fairs. One of the most popular hashtags on the network is \#food ${ }^{7}(228,718,195$ publications), followed by \#instafood $(89,919,202$ publications). It is interesting to note that glutton profiles become a kind of restaurant complement menus, with numerous pictures of the food, ambience, comments on the high-profile dishes and frustrated expectations. This is the case, for example, of the profile @fernandoecintia, a couple of lawyers with 16,900 followers on Instagram, whose brand is to go out to eat at starred restaurants and record their impressions. Another peculiarity of this network is live chefs' videos, straight from their kitchens. They often teach tricks and recipes, winning countless followers, such as Brazilian chefs Alex Atala (@alexatala, 585,000), Claude Troisgros (@c_troisgros, 252,000), Felipe Bronze (@felipebronze, 147,000), Guga Rocha (@chefgugarocha, 139 thousand), among others.

In Brazil, apps for mobile phones are yet another important niche for these digital products with a focus in gastronomy. The functionalities range from food delivery (delivery) to recipes, in addition to calorie counters and the quantity of ingredients needed to make a barbecue, for example. According to the Brazilian Association of Bars and Restaurants (Associação Brasileira de Bares e Restaurantes - Abrasel, 2016), the food delivery market handled $R \$ 9$ billion in $2015, R \$ 1$ billion more than in the previous year. One of the best-known apps is the Brazilian iFood (it'll will be

5 Interview available at: https://glo.bo/2uAZboO. Accessed on $17 / 07 / 2017$

6 "The fever of revenue videos invades Facebook." Available at: http://bit.ly/2gNpcva. Accessed on 14.12.2017.

7 Counted on 21.07.2017. called iF), launched in 2011, which gives its users access to the restaurants closest to their location, menus, photos, prices, comments and notes about dishes already ordered. The company's forecast is to reach 5 million orders served in $2017^{8}$. UberEats (it'll will be called UE), from the American transport company, was launched in December 2016 in São Paulo and in June 2017 in Rio de Janeiro and Belo Horizonte. For consumers, it allows viewing the surrounding restaurants and following the order in real time through the cell phone, with an average delivery time of 30 minutes. For the restaurant owners, it offers advice on how to organize all the delivery in the shortest possible time for the client. Aware of EU's arrival in Brazil, if bought the American company SpoonRocket, which also advises restaurants and focuses on more sophisticated food.

Considering the social and cultural importance of a phenomenon such as this, in this paper, the proposal is to analyze how the materialities impact on the interactions between consumers and restaurants, through the food delivery apps. Making an analogy with cavemen, who used tools to hunt, in today's society, the cellular phone is a high-tech apparatus, an instrument to obtain food at home or in the street. Smartphones with apps help tracking "prey", that is, looking for what to eat through digital menus in applications. Even when it is time to leave the house and decide which restaurant is worth visiting, clients access information and rankings on the web, making a prior consultation to these digital and collaborative menus. With the fork and the cell phone in hand, gastronomic memory is still produced in photos and videos about food. In this respect, the phone becomes a "new flatware" on the table.

\section{TENSIONS BETWEEN THE SYMBOLIC AND THE MATERIAL IN THE GASTRONOMIC FIELD}

More than a way of nurturing, food has symbolic value in different cultures. Aghori monks, people of Varanasi, India, eat human flesh during rituals as a reminder of mortality and the challenge of transcending the duality of life and death, according to a report in the Daily Mail. In the eyes of a large part of the world's population and the country itself, cannibalism is not an everyday practice, and is even seen with some disgust. On festive dates, food assumes several symbolic aspects in distinct cultures, such as the power to bring good fluids and energies. On New Year's Eve, Brazilians have rice with lentils, while in Japan people have toshikoshi soba, a kind of buckwheat noodles. There are also ingredients that are avoided for religious reasons, as is the case with pork for Jews and Muslims.

8 In "O aquecido mercado de apps de delivery". Available at: http://abr.ai/2tRPO08. Accessed on July 102017. 
Brazilian Journal of Operations \& Production Management

Volume 15, Número 3, 2018, pp. 413-419

DOI: 10.14488/BJOPM.2018.v15.n3.a8

The history of food, occupying its place in history, seeks to study food preferences, the symbolic meaning of food, dietary and religious prohibitions, culinary habits, etiquette, and table behavior and, in general, the relations that food keeps in each society with the myths, culture and social structures, in the taste of social processes (Santos, 2005, pp. 20-21).

Considering the symbolic paradigm in the context of food, emphasis should be given to Nicole Boivin's text "Material Cultures, material minds: The Impact of Things on Human Thought, Society, and Evolution" (2009), in which the archaeologist chronicles her research trajectory through the village of Balathal, in West India, in 1997. In her scientific journey, the author sought to understand more about architecture and spatial use in the Chalcolithic period. For this reason, she visited an archaeological site in that region. During the research, Boivin reports tensions between the symbolic and the material at various points. In one of his fieldwork, he raised the question about a red rectangular cloth suspended in the villager's room. When asked about the meaning of that item, he received answers such as "it's beautiful", "red covered the soot in the kitchen" (p. 2). Dissatisfied with the responses, he decided to rephrase the question and instead of asking what the squares meant, he asked why red soil was used to make the squares red. And he received a completely different answer: "it is used because it contains Lakshmi." In Hindu mythology, the goddess emerges from an ocean of milk, considered a symbol of health and good fortune. We draw here this passage from Boivin to exemplify how much we are a species that invents itself, in an anthropological perspective in which everything passes through the symbol. It is inherent in human nature to try to find meanings for everything. Our perception remains in a dichotomy between matter (it itself already represents) and symbol (via arbitrary codes, such as language, for example). The author herself perceives this biased view during her research: "I have betrayed my inclination to interpret everything in the material world as a symbol, that is, as something that represents something else" (Boivin, 2009, p. 8).

In this sense, Boivin proposes a crucial change for the social and human sciences, shifting our thinking from interpretive methodologies of symbols to the potency of matter. In other words, the author cries out for a new way of looking at science, without trying to find meaning for everything, letting "matter speak for itself." In this perspective, the symbolic does not separate itself from matter; it needs mediation, encompassing the body and the environment. In general, the author proposes the breaking of the Cartesian paradigm, in which body and spirit are separated: "the body by its nature is always divisible and the spirit is entirely indivisible".
This transformation concerns the way that we understand society, culture, and our own minds. It also, specifically, concerns the way that we understand the material world, and this relationship to the mind, to culture, and to society (Boivin, 2009, p. 9).

As noted by Felinto et Andrade (2005), several thinkers contributed to bringing this material dimension back to culture, such as George Simmel, Walter Benjamin, Harold Innis, Eric Havelock, Marshall Mc Luhan, Jacques Derrida and Siegfried Kracauer. From 1987, with essays on the materialities of communication, "a theoretical model, in which the determination of the senses in communicational phenomena was less important than the study of the material mechanisms that allowed the emergence of these senses, was beginning to be sketched".

From these reflections, it can be affirmed that there are tensions between the symbolic and the material in the gastronomic sphere as well. This material approach allows thinking that eating involves sensorialities by means of the five senses: touch, taste, smell, vision and hearing, all of which are related and exert an agency on the subject. The simple "croc" of a biscuit gives us the sensation of crunchiness, whereas a wilted biscuit does not give us the same pleasure. The appearance of an ugly plate, "ogre" has a distinct repercussion of our desire to eat it in relation to a "sensual" plate, well put together. Smell is another key point. There are people who cannot eat certain dishes because of their smell. A striking example is the double with white beans, a typical Brazilian dish that is hated by many, due to the peculiar and striking odor of bovine meat. At the same time, we are full of symbolism at the table. Why don't we eat barbecue for breakfast? Why do we go out for dinner?

From the point of view in which mind, body, objects, and the environment are equivalent to cognition in the study of a process; As developed by Maia et al. (2012), Edwin Hutchins' idea of distributed cognition considers that "the production of knowledge is not centered in a single individual, but through the interaction between individuals and tools present in the environment in which he lives and that help in the production of knowledge in a collaborative way" (Maia et al., 2012, p. 128).

\section{MATERIALITIES IN IFOOD AND UBEREATS}

Based on materiality theories and the concept of distributed cognition, it was proposed to analyze the iFood and UberEats applications. It was asked: What are the physical aspects of these digital products that affect the eating experience? It started with the main function of both apps: food delivery. The portable cell phone, understood here as 
something physical, with its internal pipes and connections, allows the customer to have the menu of an establishment in hand, without having to leave the house, talking to the waiter, asking questions about a particular dish and, then placing the order. Still, using these apps, you do not hear the din of the kitchen, you do not even see the ballet of waiters with their trays in the hall, and you do not even smell the food, even before it reaches the table. In these respects, we pay attention to the portability of menus and the question of presence - which applies in not being in the restaurant - as determinants of this materiality. Gumbrecht (2004) assists us in this journey in his reflections on the production of presence, noting that "even before the constitution of any meaning, an object, a materiality, a "medium", and an effect of tangibility will touch and affect the body of a person" (Felinto et Andrade, 2005, p. 81).

Economic issues are also affected: the customer does not need to hear the classic "credit or debit?" This question is repeated over and over again when paying the bill. It also saves the $10 \%$ service charge or parking, for example. That's because some establishments do not charge a delivery fee for orders made via apps.

In the introduction to the iFood app, there is a suggestion that the location feature be activated to find the restaurants closest to the client. It is worth mentioning that this is only possible due to the material resources of the application with geolocalizers. The second step inside the app is the permission to receive notifications in order to notify the customer when the request has been confirmed. Once again, the story speaks, since without satellite connections from the servers there would be no communication between iFood and restaurants. After selecting these initial settings, the client visualizes the content in a red and white interface, divided into "Next", "Japanese", "Snack" and "Pizzas" categories. At the top, there is still a search field in case you want to type the name of a specific place. As an example, if we click on pizza, the app will show us a list with different places, their logos, the distance of each one of them and the average delivery time. It is worth noting that in ifood not all dishes have a photo, a materiality that can, indeed, be decisive for the choice between certain types of food.

On the right hand side are the ratings of other customers, with a score of up to five stars, and it generates an overall average of all those who have left their opinions. Unlike the iFood website, in the application it is not possible to read users' comments, but only see the number of stars. In the subsection "Best rated", there are only establishments with a mark higher than 4.5. It is worth pointing out that this tool is used as a surveillance and punishment resource (Foucault, 1997), with differences in the disciplinary societies described by Foucault. While in the seventeenth and eighteenth centuries, surveillance was promoted by the state and the panopticon assisted in the observation of public spaces through a 360-degree structure, with smartphones, tablets and notebooks, surveillance would be distributed, as considered by Bruno (2013). In the case of delivery applications and websites, with any misstep from the cook or pizza delivery man, punishment features are accessed in the app's evaluation field. This is another material aspect that certainly has implications for restaurant practices. If the chef makes a bad dish, he receives the comment immediately. As Bruno (2013) considers:

The notion of distribution seeks to designate a reticular process, broadened and diversified, full of ambiguities, which is not confused with the idea of homogeneous surveillance, without edges or conflicts. On the contrary, the current processes of surveillance can only be understood if we take into account that the actions that constitute them are distributed by different sectors whose interests and perspectives are multiple and do not obey any unified principle (p. 26).

It is also worth mentioning that iFood has the "Discover" field divided into "Promotion", "Newbies here", "Free delivery", "Best value for money", "Trendy", and "Close to you" subsections. With these divisions, it is noticed that the materialities of the application, that is, the way it is divided, can totally change the course of those who were interested in Japanese food and, by selecting the field "Promotion", end up opting for Arab food. Or even the layout of the content increases the possibilities of a particular customer, causing him to discover the food of some establishment that never appears by selecting the subsection "Tá na moda" or "Novatos por aqui". The materiality of ifood also allows tracking the client's eating habits, since the design of the application makes a history of what has already been consumed. This data can be used by both the app developers to perfect it and by the customers, who keep records of what they have already eaten.

In the case of UberEats, the initial accreditation protocols are similar to iFood, with authorization requests for geolocation and notifications. After this step, the app opens in the main section and the big difference regarding iFood are the photos of the dishes that are made by professionals from a higher angle. The images of salads, juices, barbecues and snacks occupy almost the entire screen of the smartphone, causing a visual appeal much greater than in iFood. When scrolling the main page, it can be seen a menu whose number of pixels, the sharpness of the photos and the care with its framing favor the expectation in relation to the dishes and can motivate a request. Another interesting point of Uber Eats is the scheduling of appointments with a commitment, a feature that does not exist in iFood. With this possibility, clients can predict the time of their meals without having to 
Brazilian Journal of Operations \& Production Management

Volume 15, Número 3, 2018, pp. 413-419

DOI: 10.14488/BJOPM.2018.v15.n3.a8

wait hungry. Another feature of the app is to track the order, from the restaurant to the home, on a map in real time.

It is important to note that the EU design is cleaner, less colorful and more intuitive than iF's. The sensation is that clicking on the photo, the request is there, in the palm of your hand, as if the interface between client and cell phone disappears. At this point, the concept of immediacy, by Bolter et Grusin (2000) should be noted. In this concept, the authors discuss the resources of transparency and naturalization of the environment, giving the sensation of immersion. If the interface is transparent, it causes the user not to see the medium, but the content.

What designers often say they want is an 'interfaceless' interface, in which there are no recognizable electronic tools - no buttons, windows, scroll bars or even icons as such; instead, users move through the space, interacting with the objects 'naturally', as they do in the physical world" (Bolter et Grusin, 2000, p. 21-22).

For the authors, on the contrary side of the immediacy, there would be hypermediation, with countless contents and windows. At this point, it is noted that iFood has more segmented information in windows than EU, thus becoming more heterogeneous.

If the logic of immediacy leads one either to erase or to render automatic the act of representation, the logic of hypermediacy acknowledges multiple acts of representation and makes them visible. Where immediacy suggests a unified visual space, contemporary hypermediacy offers a heterogeneous space, in which representation is conceived [...] as a 'windowed style' itself" (Bolter et Grusin, 2000, p. 33-34).

\section{CONCLUSION}

From this exercise, it can be observed the agency of a mediatic materiality, that is, the food delivery applications affecting the bodies and decisions of consumers. It can be said that interface mediation directly influences the choices of customers in both applications. If the food is well presented, the desire to eat is awakened. This idea is coined by Lev Manovich in the book "The Language of New Media", when the author discusses the importance of the interface to the information society. For him, the interface is not neutral:

In semiotic terms, the computer interface acts as a code that carries cultural messages in a variety of media. When you use the Internet, everything you access - texts, music, video, naviga- ble spaces - passes through the interface of the browser and then, in its turn, the interface of the OS. In cultural communication, a code is rarely simply a neutral transport mechanism; usually it affects the messages transmitted with its help. For instance, it may make some messages easy to conceive and may render others regarded as unthinkable" (Manovich, 2001, p. 76).

With the study of Singular Media Products, Pereira (2016) highlights the acronym M.E.D.I.A., to discuss five areas of knowledge in the field of communication: media, entertainment, design, information, and arts. In the context of food delivery applications, design seems decisive for the choice or not of a particular dish or restaurant. However, the acronym further helps us to realize that these fields of knowledge are not separate, as proposed in the project of modernity, still in the Enlightenment period. In the essay "We were never modern" (1994), Bruno Latour questions these frontiers, raising the hypothesis that they never existed, and bringing a reductionist vision of the world in which we live. In this aspect, it was observed that the M.E.D.I.A. defined by Pereira is hybrids that interact at all times, are complete and interrelated. For this reason, to a greater or lesser extent, media, entertainment, design, information and art are embedded in this context of applications.

It could be seen how the new technologies, namely the food delivery apps iFood and Uber Eats affect the relations of the consumer subjects with this intangible good, thus responding to the present materiality. These devices suggest and condition behaviors, patterns, and therefore affect the way in which this economy is organized. With this brief exercise, the goal is to see how materiality affects our everyday habits and practices, even in the digital media universe - which "seem" to be essentially symbolic, with the transparency features used in application interfaces. By using devices such as apps, we are experimenting not only with new dishes, but also immersing ourselves in a universe mediated by bodies and their connections with smartphones, involving our sensorialities, whether they are visual, tactile, olfactory or gustatory.

\section{REFERENCES}

Almeida, M. (2015), Contribuições e limitações dos estudos culturais em pesquisas sobre recepção televisiva em "segunda tela", in: 10 Encontro Nacional de História da Mídia, UFRGS, Porto Alegre, RS, 2015.

Associação Brasileira de Bares e Restaurantes - Abrasel (2016), 29/03/2016 - Empresas faturam R\$ 9 bilhões com serviço delivery em 2015, available from: http://www.abrasel. com.br/atualidade/noticias/4232-29032016-empresas-faturam-r-9-bilhoes-com-servico-delivery-em-2015-.html (acces- 
sed 2018 Jul 30).

Boivin, N. (2009), Material Cultures, material minds: The Impact of Things on Human Thought, Society, and Evolution, Cambridge University Press, Cambridge.

Bolter, J.; Grusin, R. (2000), Remediation: understanding new media, MIT Press, Cambridge.

Bruno, F. (2013), Máquinas de ver, modos de ser: vigilância, tecnologia e subjetividade, Sulina, Porto Alegre, RS.

Fechine, Y. (2013), “Como pensar os conteúdos transmídias na teledramaturgia brasileira? Uma proposta de abordagem a partir das telenovelas da Globo", in: Lopes, M. I. V. (Org.), Estratégias de Transmidiação na Ficção Televisiva Brasileira, Editora Meridional, Porto Alegre, RS.

Felinto, E.; Andrade, V. (2005), "A vida dos objetos: um diálogo com o pensamento da materialidade da comunicação", Contemporânea, Vol. 3, available from: https://portalseer.ufba.br/index.php/contemporaneaposcom/article/ view/3448/2514 (accessed 2018 Jul 30).

Foucault, M. (1997), Vigiar e Punir: nascimento da prisão, Editora Vozes, Petrópolis, RJ.

Giustina, A. (2009), “A culinária como patrimônio cultural imaterial", Cadernos do CEOM - Espaço de memória: abordagens e práticas, Vol. 23, No. 31, available from: https:// bell.unochapeco.edu.br/revistas/index.php/rcc/article/ view/535/357. (acessed 2017 Dec 14).

Gumbrecht, H. (2004), Production of presence: what meaning cannot convey, Stanford University Press, Stanford.

Latour, B. (1994), Jamais fomos modernos: ensaio de antropologia simétrica, Editora 34, Rio de Janeiro, RJ.
Maia, A. et al. (2012), “Cognição integrada, encadeada e distribuída: breve discussão dos modelos cognitivos na cibercultura", Comunicação, Mídia e Consumo, Vol. 9, No. 26, pp. 115-34, available from: http://revistacmc.espm.br/index. php/revistacmc/article/download/346/pdf. (accessed 2017 Jul 13).

Manovich, L. (2001), The language of new media, MIT Press, Cambridge.

Marquioni, C.; Andacht, F. (2016), "Jogando com a comida: MasterChef e os recursos televisuais que tornam espetacular uma atividade ordinária", Revista da Associação Nacional dos Programas de Pós-Graduação em Comunicação, Vol. 19, No. 2, available from: http://www.compos.org.br/seer/index. php/e-compos/article/view/1230. (accessed 2017 Jan 03).

Mcluhan, M. (2005), Os meios de comunicação como extensões do homem, Editora Cultrix, São Paulo, SP.

Pereira, V. (2016), “Compreendendo os M.E.D.I.A - Mídias, Entretenimento, Design, Informação e Artes: as extensões da comunicação", Anais... XXV COMPÓs - Associação Nacional dos Programas de Pós-Graduação em Comunicação, São Paulo, SP, 2016.

Santos, C. R. A. (2005), “A alimentação e seu lugar na História: os tempos da memória gustativa", in: História - Questões \& Debates, Revista do Departamento de História da UFPR, Curitiba, PR, No. 42, pp. 11-35.

Scolari, C. (2008), Hacia la hipertelevisión. Los primeros sintomas de una nueva configuración del dispositivo televisivo, in Diálogos de la Comunicación, No. 77.

Received: 04 Jan 2018

Approved: 25 Jul 2018

DOI: 10.14488/BJOPM.2018.v15.n3.a8

How to cite: Monty, R. C. S. (2018), “Creative Economy: how the interface of Uber Eats and iFood could change your menu", Brazilian Journal of Operations \& Production Management, Vol. 15, No. 3, pp. 413-419, available from: https://bjopm.emnuvens.com.br/bjopm/article/view/427 (access year month day). 